Original Research Paper

\title{
Optimization of Process Conditions for the Production of Holocellulase by a Bacillus Species Isolated from Nahoon Beach Sediments
}

\author{
${ }^{1,2}$ Evelyn N. Fatokun, ${ }^{1,2}$ Uchechukwu U. Nwodo, ${ }^{3}$ Ademola O. Olaniran and ${ }^{1,2}$ Anthony I. Okoh \\ ${ }^{1}$ SAMRC Microbial Water Quality Monitoring Centre, University of Fort Hare, Alice, South Africa \\ ${ }^{2}$ Applied and Environmental Microbiology Research Group, \\ Department of Biochemistry and Microbiology, University of Fort Hare, Alice, South Africa \\ ${ }^{3}$ Department of Microbiology, School of Life Sciences, University of KwaZulu-Natal, Durban, South Africa
}

Article history

Received: 17-02-2017

Revised: 30-03-2017

Accepted: 08-04-2017

Corresponding Author:

Evelyn N. Fatokun

SAMRC Microbial Water

Quality Monitoring Centre,

University of Fort Hare, Alice,

South Africa

Tel: +27737896119

Fax: +27866286824

Email: evelynfatokun@gmail.com

\begin{abstract}
Production of holocellulase by a newly isolated marine Bacillus species via submerged fermentation technique at varying cultivation conditions was investigated. Enzyme production was optimized by altering one variable per time. Moreover effect of lignocellulosic saccharides in inducing cellulase and xylanase production was also investigated. The 16S ribosomal Deoxyribonucleic Acid (16S rDNA) gene sequence analysis exhibited 98\% sequence similarity of the isolate with other Bacillus species in the gene bank and was deposited with the accession number KX524510. Optimal xylanase and cellulase production was attained at $\mathrm{pH} 7$, temperature $30^{\circ} \mathrm{C}$ and agitation speed of 50 and $150 \mathrm{rpm}$. Furthermore, maximum xylanase and cellulase production were both achieved at $60 \mathrm{~h}$ corresponding to the late stationary growth stage, with activity of 16.6 and $0.061 \mathrm{U} \mathrm{mL}^{-1}$ respectively. Xylanase production was maximally induced by beechwood xylan, xylose and arabinose with activities of 13.59, 8.78 and $1.90\left(\mathrm{U} \mathrm{mL}^{-1}\right)$ respectively; while cellulase production was induced by carboxymethyl cellulose only and no cellulase activity was detected in the culture supernatant of the other carbon sources tested. Optimization increased cellulase and xylanase yields being 0.006-0.061 and 0.23-16.6 (U $\mathrm{mL}^{-1}$ ) from unoptimized to optimized respectively. The results of the study suggest the bacterial strain to be a proficient producer of cellulase and xylanase with potentials in biotechnological application.
\end{abstract}

Keywords: Xylanase, Cellulase, Lignocellulose, Optimization, Bacillus

\section{Introduction}

Holocellulase Enzymes, Cellulases (EC 3.2.1.4) and xylanases (EC 3.2.1.8), have increased relevance in several areas of agro-industrial processes including the improvement of nutritional quality of animal feed, quality of dough for various baked products, for cleaning and anti-re-deposition action in detergent industry, cotton softening and denim finishing in textiles industry (Motta et al., 2013). In addition, these enzymes could be employed as environment-friendly means of lignocellulosic waste conversion to various bioproducts (de Souza Vandenberghe et al., 2016).

Presently, commercial production of cellulases and xylanases is mostly from fungi such as Trichoderma and Aspergillus species, which may have attained maximal yield, having undergone extensive strain improvement over the years (Banerjee et al., 2010; Peterson and Nevalainen, 2012). Moreover, these commercial enzymes are still limited by the high cost of production, narrow substrate reaction and instability under industrial process dynamics (Motta et al., 2013). Consequently, considerable efforts are being made to increase microbial cellulase and xylanase production by environmental strains (Kim et al., 2007). In that context hemi (cellulolytic) bacterial strains are continuously being sourced from diverse environments with a view to finding better alternative producers or other cellulases and xylanases capable of enhancing existing commercial enzyme cocktail preparations (Banerjee et al., 2010). Therefore investigation on novel bacterial strains adaptable to industrial process dynamics and capable of 
producing cellulases and xylanases with favourable industrial characteristics is ongoing (Sepahy et al., 2011; de Souza Vandenberghe et al., 2016).

Members of the genus Bacillus are known to play significant roles in the biodegradation of organic matter during composting and are notable producers of hemi (cellulolytic) enzymes (Amore et al., 2013). Several Bacillus species includig $B$. circulans, $B$. amyloliquefaciens, B. halodurans, B. licheniformis, $B$. subtilis and $B$. mojavensis have been reported as producers of cellulase and xylanase (Ray et al., 2007; van Dyk et al., 2010; Sepahy et al., 2011; Acharya and Chaudhary, 2012). However, investigation of hemi (cellulolytic) bacteria from marine environment is on the increase due to their remarkable versatility and adaptation to heterogeneous environmental conditions (Lordan et al., 2011). These features potentiate them as producers of enzymes with characteristics adaptable to the dynamics of industrial processes.

Bacterial fermentation profile can be enhanced by optimization of the nutritional and culture conditions including initial $\mathrm{pH}$ of media, incubation temperature and agitation speed. Therefore determining the optimal variables is of utmost importance for increased production of the enzyme (Nagar et al., 2012). In this study, we report on the optimal conditions for enhanced cellulase and xylanase production by a Bacillus strain, isolated from marine beach sediments in South Africa.

\section{Materials and Methods}

\section{Source of Bacteria}

The bacterial strain was isolated from sediments of Nahoon Beach located in East London, Eastern Cape South Africa, by dilution and heat-shock method, using M1 media composed of ( $\mathrm{g} / \mathrm{L}$ natural seawater); peptone 2, yeast extract 4, starch 10, agar 18 (Mincer et al., 2002). The media were autoclaved at $121^{\circ} \mathrm{C}$ for $15 \mathrm{~min}$ and subsequently amended with filter sterilized $50 \mathrm{mg}$ $\mathrm{L}^{-1}$ nystatin. Bacterial cultivation was performed at incubation temperature of $30^{\circ} \mathrm{C}$ for 7 days. Repeated streaking was done to purify the bacterial colonies and the colonies so obtained were screened for lignocellulolytic potential. Screening was carried out to determine qualitative (hemi) cellulolytic enzymes production by formation of halo zones on Carboxymethyl Cellulose (CMC) and beechwood xylan agar for cellulase and xylanase activity respectively, on staining with grams iodine solution (Maki et al., 2012).

\section{Identification of the Bacterial Isolate by $16 S \mathrm{rDNA}$}

Molecular identification of the isolate was carried out by sequence investigation of the $16 \mathrm{~S}$ rRNA gene. The bacterial DNA was extracted and amplified by Polymerase Chain Reaction (PCR) following the protocol of Cosa et al. (2012). Briefly, DNA template was prepared by suspending a loop-full of bacterial colonies in $70 \mu \mathrm{L}$ of sterile distilled water, heated in a heating block (Lasec, South Africa) for 10 min at $100^{\circ} \mathrm{C}$ and cooled for $5 \mathrm{~min}$ followed by centrifuging at 3000 rpm for $5 \mathrm{~min}$. The supernatant obtained was placed in a sterile Eppendorf tube and preserved at $4^{\circ} \mathrm{C}$, for further analysis. The PCR was run using a universal gene primer with the following forward and reverse primers: F1: 59AGAGTTTGATCITGGCTCAG-39; I = inosine and R5: 59-ACGGITACCTTGTTACGACTT-39 respectively and a $2 \mu \mathrm{L}$ template DNA. Nearly full-length of the 16S rDNA nucleotide sequences were amplified. The amplicon size was confirmed by $1 \%$ agarose gel electrophoresis (Cosa et al., 2012) and sequenced at University of Kwa-Zulu Natal, Durban (South Africa). Verification of the bacterial genus was by Basic Local Alignment Search Tool (BLAST) algorithm system of National Centre for Biotechnology (http://www.ncbi.nlm.nih.gov/Blast.cgi). Sequences from the GenBank database and the bacterial strain were aligned with the MUSCLE programme via the EMBLEBI portal (www.ebi.ac.uk/Tools/msa/muscle/). The evolutionary analyses and construction of the tree topology of the aligned sequences were conducted in MEGA 6 programme using Maximum Likelihood method based on Jukes-Cantor model (Tamura et al., 2013).

\section{Cultivation Media and Fermentation Conditions}

Fermentation and pre-culture medium was composed of $(\mathrm{g} / \mathrm{L}) ; 0.1 \% \mathrm{NaNO}_{3}, 0.05 \% \mathrm{MgSO}_{4}, 0.1 \% \mathrm{~K}_{2} \mathrm{HPO}_{4}$, $0.1 \% \mathrm{KCl}, 0.05 \%$ yeast extract, $1 \%$ carboxymethyl cellulose (Merck, South Africa) or beechwood xylan (ROTH, South Africa). All fermentations were performed in $250 \mathrm{~mL}$ Erlenmeyer flasks. Sterilization of the cultivation media was carried out by autoclaving for $15 \mathrm{~min}$ at $121^{\circ} \mathrm{C}$, after adjusting the initial $\mathrm{pH}$ to 7.0 (Maki et al., 2012). Preparation of the culture inoculum was performed by placing a loopful of bacterial colony into a test tube containing $5 \mathrm{~mL}$ of medium and incubated at $30^{\circ} \mathrm{C}$ for $24 \mathrm{~h}$. Thereafter optical density of the inoculum was adjusted to $0.1\left(\mathrm{OD}_{600}\right)$ using sterile normal saline, $1 \mathrm{~mL}$ of which was subsequently transferred into $100 \mathrm{~mL}$ of sterile cultivation medium. Fermentation was performed by incubating in a rotary gyrator at $140 \mathrm{rpm}$ and $30^{\circ} \mathrm{C}$ for $72 \mathrm{~h}$. Fermentation broth was centrifuged at $10,000 \mathrm{rpm}$ for $15 \mathrm{~min}$ under $4^{\circ} \mathrm{C}$ and the supernatant so obtained served as crude extracellular enzyme (Sharma et al., 2013).

\section{Enzyme Assay}

Quantitation of cellulase and xylanase production was determined by volumetric enzyme activity following the method of Saratale et al. (2012), with slight modifications. Estimation of released reducing sugar from carboxymethyl cellulose and beechwood xylan was in accordance with Miller (1959), using the 3, 5Dinitrosalicylic Acid (DNS) method. 


\section{Cellulase Assay}

Cellulase activity was determined by a reaction volume comprising $1 \mathrm{~mL}$ of crude extracellular enzyme and $1 \mathrm{~mL}$ of $1 \%(\mathrm{w} / \mathrm{v})$ carboxymethyl cellulose (Merck, Modderfontein, South Africa) dissolved in $50 \mathrm{mM}$ phosphate buffer ( $\mathrm{pH} 7.0$ ), which was incubated in a water bath (Lasec, South Africa) at $50^{\circ} \mathrm{C}$ for $30 \mathrm{~min}$.

\section{Xylanase Assay}

Xylanase activity assay was conducted by adding $1 \mathrm{~mL}$ suitably diluted enzyme to $1 \mathrm{~mL}$ of $1 \%(\mathrm{w} / \mathrm{v})$ beechwood xylan (ROTH, Cape Town, South Africa), in $50 \mathrm{mM}$ phosphate buffer ( $\mathrm{pH}$ 7). The enzyme and substrate reaction mixture was incubated for $10 \mathrm{~min}$ at $50^{\circ} \mathrm{C}$. Sample controls were subjected to the same reaction conditions but were terminated at zero time. Reactions were terminated by adding $2 \mathrm{~mL} \mathrm{3,5-}$ Dinitrosalicylic (DNS) acid reagent, placed in a vigorously boiling water bath for $10 \mathrm{~min}$ and cooled in ice water. The absorbance reading was taken at $540 \mathrm{~nm}$ and the reducing sugars released were estimated using D-glucose and D-xylose standard line graphs, for cellulase and xylanase activity respectively. One unit of enzyme was defined as the amount of enzyme per millilitre needed to liberate one micromole of reducing sugar from CMC or beechwood xylan per minute under the stated assay conditions.

\section{Determination of Optimal Fermentation Conditions for Holocellulase Production}

Submerged fermentation of cellulase and xylanase was carried out at varying cultivation conditions by adjusting one variable while keeping others constant (Battan et al., 2007). Optimized conditions were then used in consecutive optimization fermentation (Fatokun et al., 2016).

\section{Effect of Initial pH on Holocellulase Production}

The effect of initial $\mathrm{pH}$ on cellulase and xylanase production was investigated by altering initial $\mathrm{pH}$ of the medium with $1 \mathrm{~N} \mathrm{HCl}$ or $1 \mathrm{~N} \mathrm{NaOH}$. Adjustment of the $\mathrm{pH}$ ranged from 3-11 before sterilization and was subsequently incubated under the earlier stated conditions.

\section{Effect of Incubation Temperature on Holocellulase Production}

A $100 \mathrm{~mL}$ of fermentation medium in $250 \mathrm{~mL}$ Erlenmeyer flask was inoculated with a $1 \mathrm{~mL}$ inoculum of the bacterial suspension adjusted to optical density of $0.1\left(\mathrm{OD}_{600}\right)$ and incubated at different temperatures ranging from $25-50^{\circ} \mathrm{C}$ for $72 \mathrm{~h}$. Thereafter the fermentation medium was centrifuged at $10,000 \mathrm{rpm}$, $4^{\circ} \mathrm{C}$ for $15 \mathrm{~min}$ and the supernatant was used for assaying activity of the extracellular enzymes.

\section{Optimizing Agitation Speed for Holocellulase Production}

Cellulase and xylanase production was carried out under static and different agitation speed. Agitation speed was adjusted from 50-200 rpm, with an interval of $50 \mathrm{rpm}$ and was incubated at pre-optimized conditions for $72 \mathrm{~h}$.

\section{Kinetics of Growth and Production of Holocellulase over Time}

A $1 \mathrm{~mL}$ of $24 \mathrm{~h}$ pre-culture adjusted to 0.1 Optical Density $\left(\mathrm{OD}_{600}\right)$ was used in seeding $100 \mathrm{~mL}$ of fermentation medium and incubated under optimized conditions for $96 \mathrm{~h}$. The medium was withdrawn at $12 \mathrm{~h}$ interval to monitor growth and enzyme activity. Growth was recorded as change in optical absorbance at $\mathrm{OD}_{600}$.

\section{Effect of Carbon Source on Holocellulase Production}

The basal salts medium was supplemented with different carbon source in order to determine their effect in inducing cellulase and xylanase production by the bacterial strain. Carbon source components of lignocellulose were selected which were; crystalline cellulose in form of Avicel, carboxymethyl cellulose, xylan (beechwood xylan), cellobiose, arabinose, galactose, glucose, mannose and xylose were individually added at a concentration of $1 \%(\mathrm{w} / \mathrm{v})$ in the fermentation broth. The monosaccharides were sterilized separately prior to mixing with the basal salts medium. Basal salts medium without a carbon supplement served as control fermentation broth. Microbial fermentation was performed for $72 \mathrm{~h}$; after which the broth was centrifuged and assayed for extracellular volumetric enzymes activity.

\section{Statistical Analysis}

All the experiments were run in triplicates and data obtained were recorded as mean standard deviation. Comparison of mean was by Fisher's Least Significant Difference following one-way Analyses of Variance (ANOVA), using Statistical Package for Social Sciences (SPSS) run with IBM SPSS Statistics 23 Software (IBM Corp, New York, USA). A $\mathrm{p} \leq 0.05$ between variables was considered significant.

\section{Results}

According to the BLAST analysis of $16 \mathrm{~S}$ rDNA sequence, the isolate in this study belongs to the Bacillus genus, with a $98 \%$ similarity with other Bacillus species in the gene bank including Bacillus cereus strainAPT23, B. thuringiensis strain KUDC1706 and B. cereus strain MSCS33; was consequently named Bacillus sp. strain SAMRC-UFH9 and deposited at the gene data base under the accession number KX524510. Phylogenetic tree generated showing the evolutionary relationship of the strain with other Bacillus strains in Gen Bank database is shown in Fig. 1. 


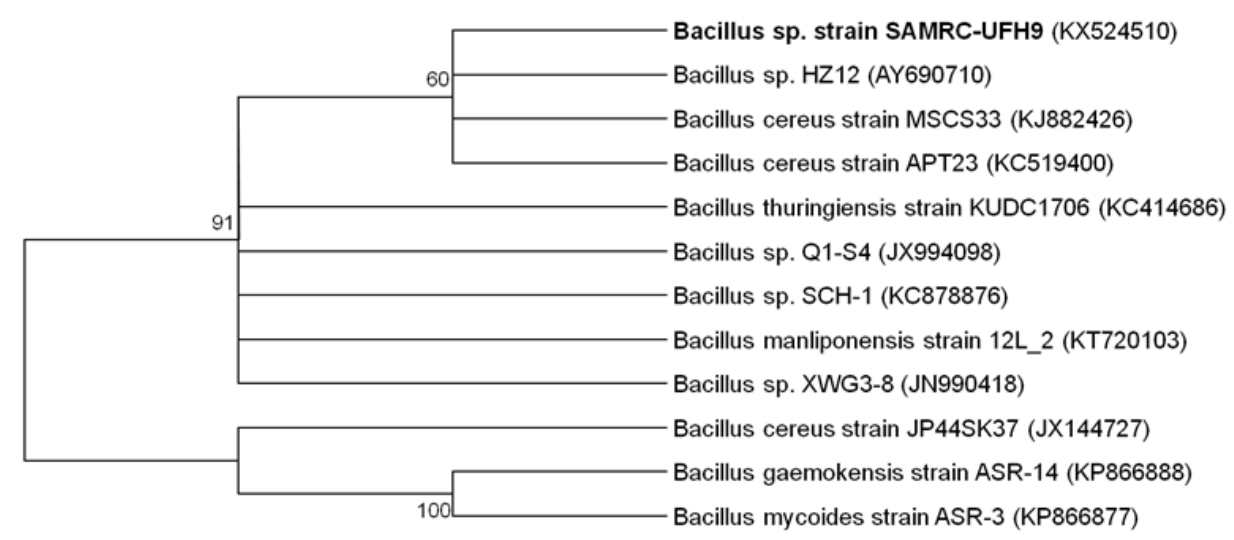

Fig. 1. Phylogenetic tree of Bacillus sp. strain SAMRC-UFH9 with other Bacillus strains in the gene bank. The tree topology with higher log likelihood value was selected; and the Bootstrap values $(>50 \%)$ of 1000 replicates are indicated next to the branches (Tamura et al., 2013)

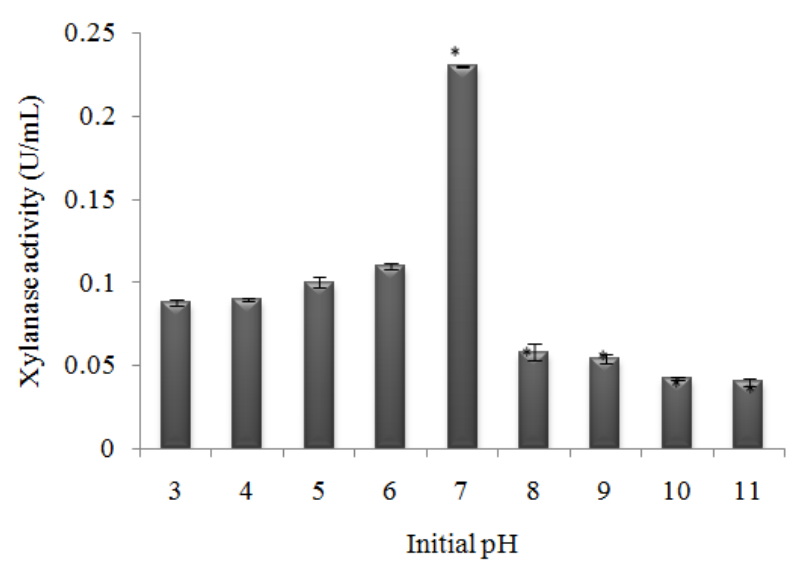

(A)

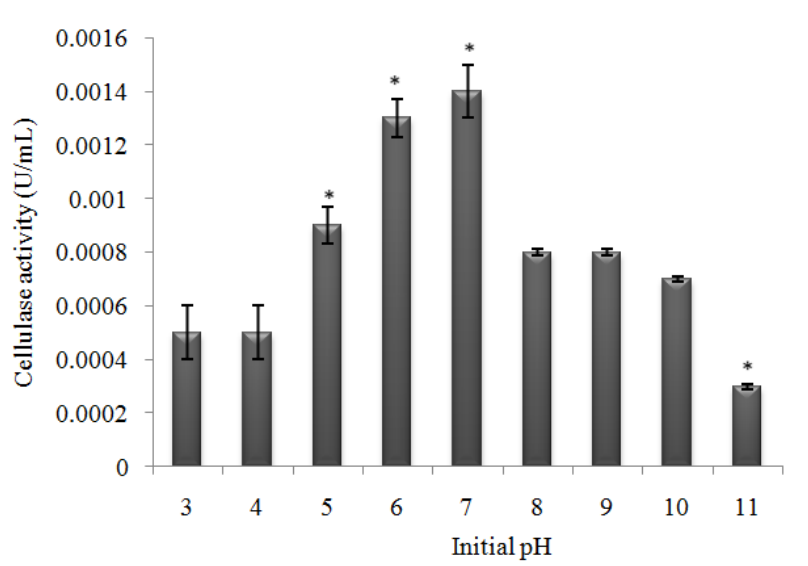

(B)

Fig. 2. Effect of initial $\mathrm{pH}$ on xylanase (A) and cellulase (B) production. There was statistical significance between pH ranges but cellulase production was at a wider $\mathrm{pH}$ range (5-9). Optimal production was at $\mathrm{pH} 7$ for both xylanase and cellulase. Values are mean of triplicate tests $\pm \mathrm{SD}$. Asterisk denotes significant difference in xylanase and cellulase production at $\mathrm{p} \leq 0.05$

\section{Effect of Initial pH on Holocellulase Production}

Effect of initial $\mathrm{pH}$ of medium on cellulase and xylanase production was investigated (Fig. 2). Although significant difference was observed between the $\mathrm{pH}$ ranges $(\mathrm{p}<0.05)$, no statistical significance was observed between $\mathrm{pH} 3$ and 4 and $\mathrm{pH} 5$ and 6 for xylanase production. Optimal xylanase production was at initial pH 7 with activity of $0.23 \pm 0.001 \mathrm{U} \mathrm{mL}^{-1}$. A decline in production was observed with increase in $\mathrm{pH}$ and the least recorded was at $\mathrm{pH} 11$ with activity of $0.04 \pm 0.0 \mathrm{U}$ $\mathrm{mL}^{-1}$ (Fig. 2A). While there was significant difference $(\mathrm{p}<0.05)$ among the $\mathrm{pH}$ variables for cellulase production, there was no significant difference in its production between $\mathrm{pH} 3$ and 4 and between $\mathrm{pH} 8,9$ and 10. Furthermore, cellulase production by the Bacillus sp. strain SAMRC-UFH9 was at a wide $\mathrm{pH}$ range from 5-9 (Fig. 2B) and maximum production was observed between initial $\mathrm{pH} 6$ and 7 with respective activity of $0.0013 \pm 0.0001$ and $0.0014 \pm 0.0001 \mathrm{U} \mathrm{mL}^{-1}(\mathrm{p}>0.05)$, whereas the least cellulase production was at $\mathrm{pH} 11$ with activity of $0.0003 \pm 0.0 \mathrm{U} \mathrm{mL}^{-1}$.

\section{Effect of Incubation Temperature}

Optimal temperature for xylanase and cellulase production by the Bacillus strain was investigated and the result is shown in Fig. 3. Xylanase was produced under all the incubation temperature range tested, nevertheless optimal production was recorded at $30^{\circ} \mathrm{C}(0.24 \pm 0.01 \mathrm{U}$ $\mathrm{mL}^{-1}$ ) and there was no statistical significance between xylanase produced at 35 and $40^{\circ} \mathrm{C}$. Furthermore, about $50 \%$ of the xylanase activity recorded at the optimal temperature was attained at the temperature range of $45-50^{\circ} \mathrm{C}$ (Fig. 3A). On the other hand cellulase production was more sensitive to temperature difference, as indicated by a maximum production at $30^{\circ} \mathrm{C}\left(0.015 \pm 0.001 \mathrm{U} \mathrm{mL}^{-1}\right)$ and almost no production being recorded at temperature range of $40-50^{\circ} \mathrm{C}$ (Fig. 3B). There was no significant difference between temperatures 40,45 and $50^{\circ} \mathrm{C}$, with respective activity of $0.0003 \pm 0.0,0.0001 \pm 0.0$ and $0.0001 \pm 0\left(\mathrm{U} \mathrm{mL}^{-1}\right)$. 


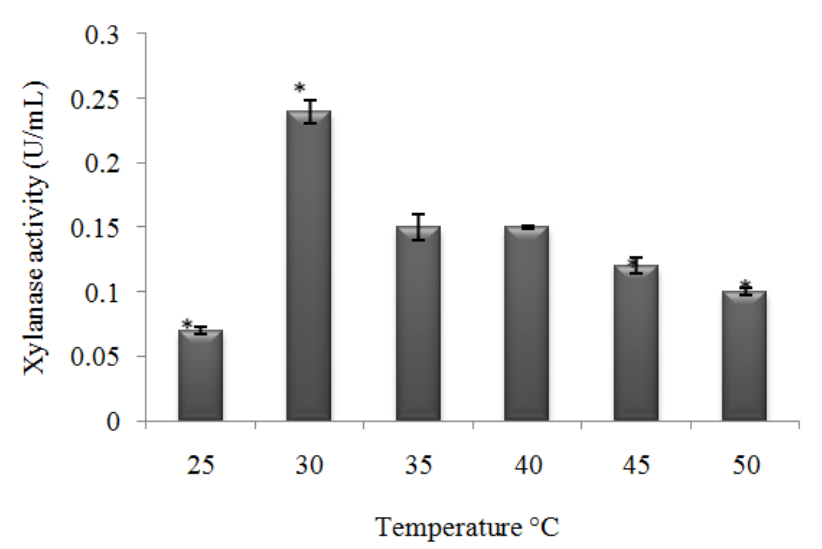

(A)

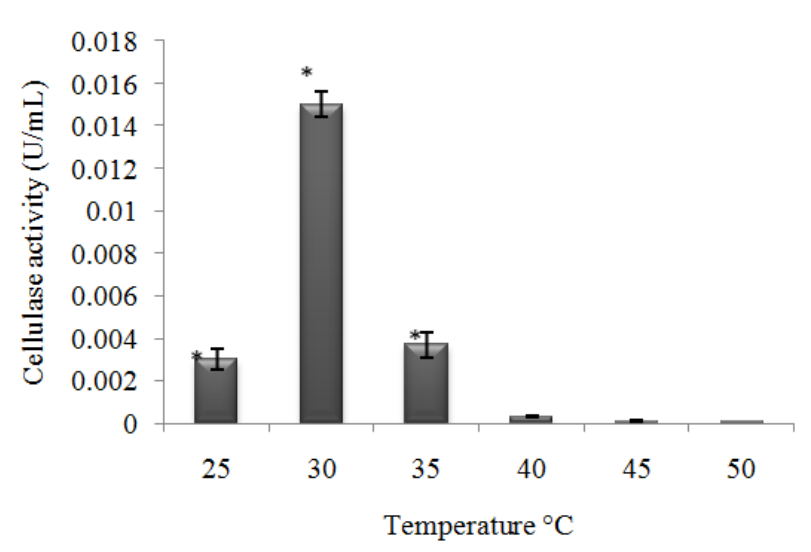

(B)

Fig. 3. Effect of incubation temperature on xylanase (A) and cellulase (B) production. Xylanase production was recorded under all the incubation temperature range tested and up to $50 \%$ of the activity at optimal incubation temperature was attained at the temperature range of $45-50^{\circ} \mathrm{C}$. Cellulase production was more sensitive to temperature difference and nearly no production at $45-50^{\circ} \mathrm{C}$. Values are mean of triplicate tests $\pm \mathrm{SD}$. Asterisk denotes a significant difference in xylanase and cellulase production at $\mathrm{p} \leq 0.05$

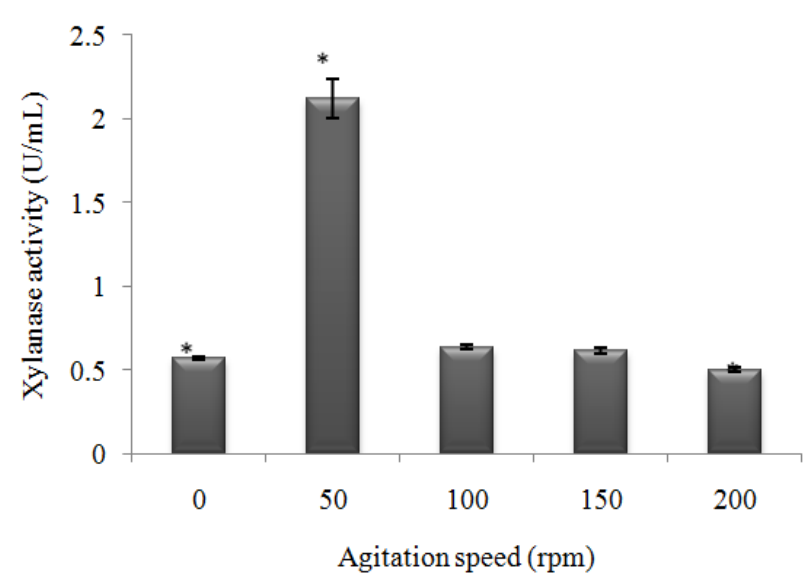

(A)



(B)

Fig. 4. Effect of static (0) and varying agitation speed for xylanase (A) and cellulase (B) production by Bacillus sp. strain SAMRC-UFH9. Xylanase and cellulase production was favoured by low agitation speed $(50 \mathrm{rpm})$, while cellulase production was favoured by higher agitation speed of $150 \mathrm{rpm}$. Asterisk denotes a significant difference in xylanase and cellulase production at $\mathrm{p} \leq 0.05$

\section{Optimizing for Agitation Speed}

Production of cellulase and xylanase by Bacillus sp. strain SAMRC-UFH9 under static condition and varying agitation speed was investigated and the result is as presented in Fig. 4. Xylanase production was favoured by low speed of $50 \mathrm{rpm}$ with a maximum activity of $2.5 \pm 0.13 \mathrm{U} \mathrm{mL}^{-1}$ (Fig. 4A). Other recorded xylanase production was at respective agitation speed of 100 and $150(\mathrm{rpm})$ with activities of $0.8 \pm 0.02$ and $0.73 \pm 0.02\left(\mathrm{U} \mathrm{mL}^{-1}\right)$, although the difference between the two was not statistically significant. The least xylanase production was recorded at $200 \mathrm{rpm}$, followed by static condition with activities of $0.5 \pm 0.01$ and $0.7 \pm 0.0\left(\mathrm{U} \mathrm{mL}^{-1}\right)$ respectively. Conversely, cellulase production was favoured by higher agitation speed of $150 \mathrm{rpm}$ with activity of $0.037 \pm 0.001 \mathrm{U} \mathrm{mL}^{-1}$. Other observed cellulase production in order of descent were, $0.025 \pm 0.001,0.023 \pm 0.002$ and $0.022 \pm 0.002\left(\mathrm{U} \mathrm{mL}^{-1}\right)$ at agitation speed of 200, 100 and $50(\mathrm{rpm})$ respectively.

\section{Growth and Time Course for Xylanase and Cellulase Production}

Xylanase and cellulase production was carried out over $96 \mathrm{~h}$ period and the microbial growth $\left(\mathrm{OD}_{600}\right)$ and activity at $12 \mathrm{~h}$ interval are as shown in Fig. 5. Xylanase production was initiated after $12 \mathrm{~h}$ with gradual increase at $48 \mathrm{~h}$ (Fig. 5A), corresponding to the early stationary growth phase. Peak in xylanase production was attained 
at $60 \mathrm{~h}\left(16.6 \pm 0.3 \mathrm{U} \mathrm{mL}^{-1}\right)$, towards the mid stationary growth, which sharply declined at $72 \mathrm{~h}$ and finally dropped at $96 \mathrm{~h}$ with activity of $4.42 \pm 0.2 \mathrm{U} \mathrm{mL}^{-1}$. On the other hand cellulase production was also initiated at $12 \mathrm{~h}$ but remained steady till $36 \mathrm{~h}$ when there was a gradual increase and attained optimal production at $60 \mathrm{~h}$ $\left(0.061 \pm 0.002 \mathrm{U} \mathrm{mL}^{-1}\right)$ as well. However, another peak in cellulase production was observed at $96 \mathrm{~h}(0.06 \pm 0.01 \mathrm{U}$ $\left.\mathrm{mL}^{-1}\right)$ after an initial decline at $72 \mathrm{~h}\left(0.054 \pm 0.0007 \mathrm{U} \mathrm{mL}^{-1}\right)$ corresponding to the late stationary growth phase (Fig. 5B).

\section{Effect of Carbon Source for Holocellulase Production}

The production of holocellulase enzymes by Bacillus sp. strain SAMRC-UFH9 in response to carbon source

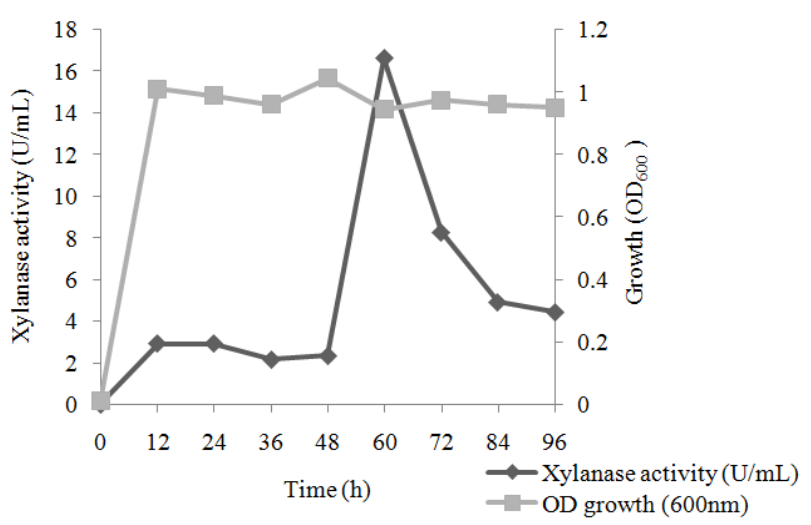

(A) was investigated and the result is presented in Fig. 6 . Xylanase production was maximally induced by beechwood xylan with an activity of $13.59 \pm 0.33 \mathrm{U} \mathrm{mL}^{-1}$, followed by xylose and arabinose with activity of $8.78 \pm 0.31$ and $1.9 \pm 0.04\left(\mathrm{U} \mathrm{mL}^{-1}\right)$ respectively. Xylanase production was also induced by other carbon sources but at much reduced activity with the following ascending order of activity: $0.41 \pm 0.01,0.44 \pm 0.02,0.47 \pm 0.06$, $0.51 \pm 0.01,0.54 \pm 0.03$ and $0.75 \pm 0.02\left(\mathrm{U} \mathrm{mL}^{-1}\right)$, for glucose, mannose, cellobiose, microcrystalline cellulose, $\mathrm{CMC}$ and galactose respectively. On the contrary cellulase production was induced by $\mathrm{CMC}$ only $\left(0.052 \pm 0.002 \mathrm{U} \mathrm{mL}^{-1}\right)$; no cellulase activity was detected in culture supernatant of the other carbon sources.

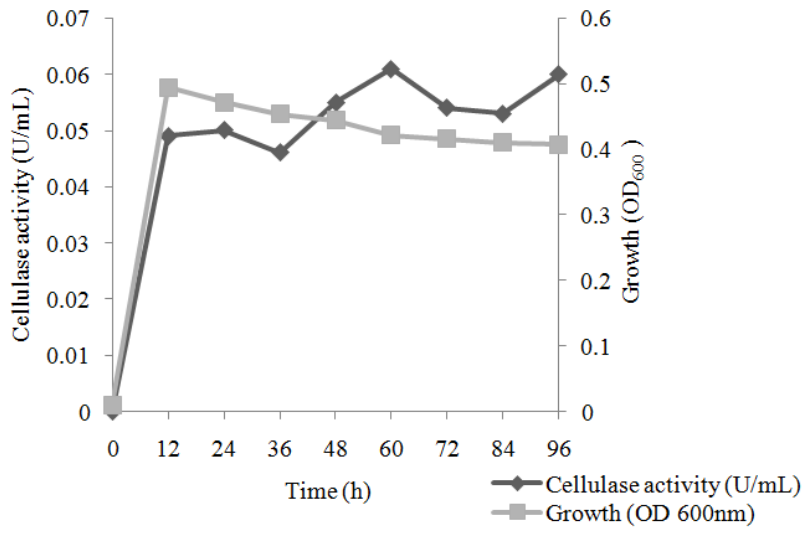

(B)

Fig. 5. Growth and time course for xylanase (A) and cellulase (B) production by Bacillus sp. strain SAMRC-UFH9. Readings were taken at $12 \mathrm{~h}$ interval and values represent triplicate tests. Peak xylanase and cellulase production were both attained at $60 \mathrm{~h}$, at mid stationary growth. Xylanase production sharply declined at $72 \mathrm{~h}$ and finally dropped at $96 \mathrm{~h}$ while gradual drop in cellulase production occurred between $72-84 \mathrm{~h}$ and picked up at $96 \mathrm{~h}$

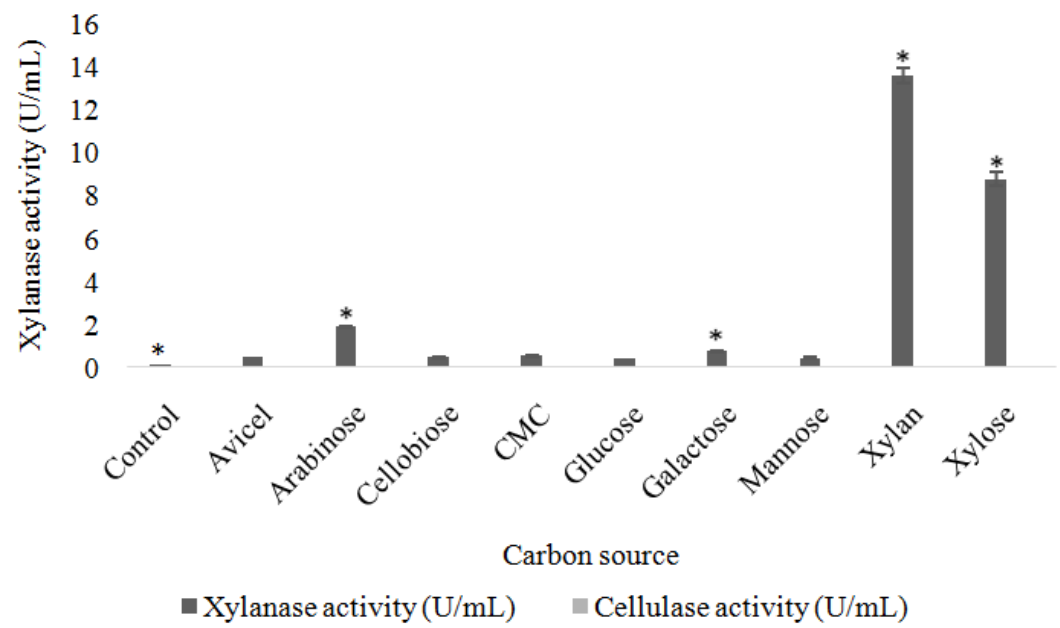

Fig. 6. Carbon inducers of xylanase and cellulase production by Bacillus sp. strain SAMRC-UFH9. Xylanase production was induced by all the carbon source tested; cellulase production was induced by CMC only. Xylanase production was maximally induced by Beechwood Xylan; followed by xylose and arabinose. Glucose was the least carbon inducer of xylanase production by the Bacillus strain. Asterisk denotes a significant difference in xylanase and cellulase production at $\mathrm{p} \leq 0.05$ 


\section{Discussion}

Optimizing various culture conditions is considered as one of the paramount criteria in developing any novel microbial process (Anbu et al., 2013). Moreover, response to cultivation conditions are as varied as the microbial population (Table 1), hence optimal conditions for cellulase and xylanase production by any microorganism have to be ascertained in order to maximize product yield (Ray et al., 2007).

\section{Effect of Initial pH on Holocellulase Production}

Studies have shown that $\mathrm{pH}$ of cultivation medium exerts a great influence on microbial growth and metabolic activities (Saini et al., 2014). Similar findings with this study for the optimal initial $\mathrm{pH} 7$ for xylanase production have been reported in previous studies on Bacillus species, including B. pumilus ASH, Bacillus altitudinis DHN8, $B$. amyloliquefaciens XR44A and B. vallismortis RSPP-15 (Sanghi et al., 2008; Adhyaru et al., 2014; Amore et al., 2013; Gaur et al., 2015). Contrary to this result however, optimal initial $\mathrm{pH}$ varied for xylanase production by $B$. megaterium ( $\mathrm{pH}$ 7.5), B. subtilis $(\mathrm{pH}$ 8) and B. pumilus VLK-1 (pH 6), (Tandon and Sharma, 2014; Kumar et al., 2014). Nevertheless, the result of this study concurs with previous reports for cellulase production by most Bacillus species (Abou-Taleb et al., 2009; Bai et al., 2012). In contrast, $\mathrm{pH} 6.5$ was optimal for both Bacillus licheniformis MVS1 and Bacillus sp. MVS3; while pH 8 was optimum for cellulase production by Bacillus sp. 313SI using pretreated rice straw as carbon source (Acharya and Chaudhary, 2012; Goyal et al., 2014). Sharma et al. (2013) accounted that initial $\mathrm{pH} 6.5$ and 7.5 were optimal for cellulase production and $\mathrm{pH} 7.5$ and 8 for xylanase production by $B$. licheniformis, Bacillus sp., $B$. megaterium and B. subtilis respectively.

\section{Effect of Incubation Temperature}

Metabolic reaction rate is influenced by temperature differential since cellular metabolic activity is slowed down at temperatures below or above the optimal reaction temperature range (Tandon and Sharma, 2014). Therefore optimal temperatures are paramount for efficient microbial growth and enzyme production. Similar finding to this study was made by other authors who reported $30^{\circ} \mathrm{C}$ as optimal temperature for xylanase and cellulase production by different Bacillus species (Nagar et al., 2012; Bai et al., 2012; Kumar et al., 2014); and very close to the finding of Mukesh Kumar et al. (2012) who reported that $32^{\circ} \mathrm{C}$ was optimal for cellulase production by $B$. cereus MRK1.

Table 1. Optimization conditions, cellulase and xylanase yield for some Bacillus strains

\begin{tabular}{|c|c|c|c|c|c|c|c|c|c|c|c|}
\hline \multirow[b]{2}{*}{ Bacillus strain } & \multicolumn{5}{|c|}{ Cellulase optimization conditions } & \multicolumn{6}{|c|}{ Xylanase optimization conditions } \\
\hline & Substrate & $\mathrm{pH}$ & $\mathrm{t}\left({ }^{\circ} \mathrm{C}\right)$ & $\mathrm{FP}(\mathrm{h})$ & $\begin{array}{l}\text { Cellulase } \\
\text { yield }\end{array}$ & Substrate & $\mathrm{pH}$ & $\mathrm{t}\left({ }^{\circ} \mathrm{C}\right)$ & $\mathrm{FP}(\mathrm{h})$ & $\begin{array}{l}\text { xylanase } \\
\text { yield }\end{array}$ & References \\
\hline B. cereus MRK1 & Xylan & 8 & 32 & 48 & - & - & - & - & - & - & $\begin{array}{l}\text { Mukesh Kumar et al. } \\
\text { (2012) }\end{array}$ \\
\hline $\begin{array}{l}\text { B. subtilis KIBGE-HAS } \\
\text { B. subtilis CY5 }\end{array}$ & $\mathrm{SC} / \mathrm{MC}$ & 7 & 40 & 48 & $302^{\mathrm{a}}$ & & - & - & - & - & Bano et al. (2013) \\
\hline $\begin{array}{l}\text { B. circulans TP3 } \\
\text { B.licheniformis } \text { MVS1 }\end{array}$ & $\mathrm{CMC} / \mathrm{MC}$ & 7.5 & 40 & 96 & - & - & - & - & - & - & Ray et al. (2007). \\
\hline Bacillus sp. MVS3 & $\mathrm{WS} / \mathrm{MC}$ & $6.5 ; 7$ & 50 & 60 & - & - & - & - & - & - & $\begin{array}{l}\text { Acharya and Chaudhary } \\
\text { (2012) }\end{array}$ \\
\hline Bacillus sp. JS14 & WB & 6.5 & 40 & 120 & $2014^{\mathrm{b}}$ & - & - & - & - & - & Singh and Kaur (2012) \\
\hline Bacillus sp. BCCS A3 & $\mathrm{CMC} / \mathrm{MC}$ & 9 & - & - & $49.80^{\mathrm{c}}$ & - & - & - & - & - & Kazemi et al. (2014) \\
\hline $\begin{array}{l}\text { B. amyloliquefaciens } \\
\mathrm{SS}_{35}\end{array}$ & $\mathrm{CMC} / \mathrm{MC}$ & 6 & 40 & 48 & $\begin{array}{l}0.161^{c} \\
-0.693^{c} \\
\text { (4-fold) }\end{array}$ & - & - & - & - & - & Singh et al. (2014) \\
\hline B. subtilis ASH & - & - & - & - & - & WB & 7 & 37 & 72 & - & Sanghi et al. (2008) \\
\hline B. pumilus SV-205 & - & - & - & - & - & $\mathrm{WB} / \mathrm{MC}$ & 10 & 37 & 36 & $\begin{array}{l}7382.7^{\mathrm{b}} \\
(21.63 \text { fold })\end{array}$ & Nagar et al. (2012) \\
\hline B. halodurans TSEV1 & - & - & - & - & - & $\mathrm{WB} / \mathrm{MC}$ & - & - & - & 23 -fold & $\begin{array}{l}\text { Kumar and } \\
\text { Satyanarayana (2014) }\end{array}$ \\
\hline B. vallismortis RSPP 15 & - & - & - & - & - & BWX & 7 & 55 & 48 & $3768^{\mathrm{b}}$ & Gaur et al. (2015) \\
\hline B. pumilus ASH & - & - & - & - & - & WB & 8 & 37 & 72 & $5407^{\mathrm{b}}$ (13-fold) & Battan et al. (2007) \\
\hline B. halodurans $\mathrm{PPKS}-2$ & - & - & - & - & - & OsX/MC & 11 & 37 & 48 & 4 -fold & Prakash et al. (2012) \\
\hline B. mojavensis AG137 & - & - & - & - & - & $\mathrm{Ob} / \mathrm{MC}$ & 8 & 37 & 48 & $194.68^{\mathrm{b}}-302.466^{\mathrm{b}}$ & Sepahy et al. (2011) \\
\hline B. altitudinis DHN8 & - & - & - & - & - & SS & 7.0 & 35 & 42 & 3.74-fold increase & Adhyaru et al. (2014) \\
\hline B. subtilis $276 \mathrm{NS}$ & $\mathrm{X} / \mathrm{CMC} / \mathrm{S}$ & 8 & 35 & 24 & 5.7-fold & $\mathrm{X} / \mathrm{CMC} / \mathrm{S}$ & 8.0 & 35 & 24 & 1.08-fold & Ali et al. (2013) \\
\hline $\begin{array}{l}\text { Bacillus isolates } \\
\text { (MAM-29 and } \\
\text { MAM-38) }\end{array}$ & RS & $6.4 ; 5.6$ & 50 & 48 & $\begin{array}{l}200^{c} \\
-311^{c} \\
203^{c}-325^{c}\end{array}$ & RS & $5 ; 4$ & 50 & 48 & $\begin{array}{l}162-233^{\mathrm{b}} \\
153-242^{\mathrm{b}}\end{array}$ & Abo-State et al. (2013) \\
\hline $\begin{array}{l}\text { Bacillus isolates } \\
\text { ( } \mathrm{R} 5 \text { and } \mathrm{N} 11 \text {; } \\
\mathrm{K}_{22} \text { and } \mathrm{K}_{23} \text { ) }\end{array}$ & BSM & $6.5 ; 5.6$ & $30 ; 35$ & $168 ; 120$ & $\begin{array}{l}169.553 \% \\
\left(\mathrm{~K}_{22}\right) \\
181.346 \% \\
\left(\mathrm{~K}_{23}\right)\end{array}$ & TGY & 7.58 .0 & 45,40 & 168 & $428.997 \%$ & $\begin{array}{l}\text { Sharma et al. }(2013) \text {. } \\
\left(\mathrm{R}_{5}\right) \\
464.512 \% \\
\left(\mathrm{~N}_{11}\right)\end{array}$ \\
\hline $\begin{array}{l}\text { Bacillus sp. strain } \\
\text { SAMRC-UFH9 }\end{array}$ & $\mathrm{CMC}$ & 7 & 30 & 60 & $\begin{array}{l}0.0056- \\
0.061^{\mathrm{c}} \\
(10.89 \text {-fold })\end{array}$ & $\mathrm{BX}$ & 7 & 30 & 60 & $\begin{array}{l}0.23-16.6^{c} \\
(72.17-\text { fold })\end{array}$ & This study \\
\hline
\end{tabular}


Contrary to the result of this study however, maximum production of xylanase and cellulase by other bacterial species at both lower and higher incubation temperatures have been reported (Sepahy et al., 2011; Bibi et al., 2014), which is suggestive that optimal incubation temperature for cellulase and xylanase production is dependent on bacterial strain (Gautam et al., 2011).

\section{Optimizing for Agitation Speed}

Agitation and aeration are crucial factors responsible for oxygen supply and uniform distribution of nutrients under submerged fermentation process, for enhanced microbial growth and enzymes production (Satyanarayana and Adhikari, 2006). Agitation speed for optimal xylanase production recorded in this study (50 $\mathrm{rpm}$ ), seems contradictory to the findings of Sanghi et al. (2009) who reported agitation speed of $200 \mathrm{rpm}$ as optimal for xylanase production by B. subtilis ASH and some other authors who reported xylanase production to be optimal under static condition (Saratale et al., 2012). Nevertheless, Irfan et al. (2012) affirmed that B. subtilis had maximal xylanase production at both static and 140 rpm using sugarcane bagasse and wheat bran respectively. However, the optimal agitation speed for cellulase production observed in this study corroborates that of other authors that reported $150 \mathrm{rpm}$ to be optimal for cellulase production by different bacterial strains including $B$. alcalophilus and B. amyloliquefaciens with respective activity of 2.32 and $2.97 \mathrm{IU} \mathrm{mL}^{-1}$; Achromobacter xylosoxidans BSS4, Pseudomonas sp. BSS2 and Bacillus sp. BSS3 with activity 104.68, 91.28 and $68.22 \mathrm{U} \mathrm{mL}^{-1}$ respectively (Abou-Taleb et al., 2009; Sreedevi et al., 2013). Conversely Deka et al. (2013) recorded agitation speed of $121 \mathrm{rpm}$ as optimal for CMCase production by $B$. subtilis. Low agitation speed especially in high viscous CMC broth, may result in low level of Dissolved Oxygen (DO), which may be insufficient for microbial growth and metabolic activity (Sarka and Aikat, 2014). Therefore, differences in response to static and varying agitation speed for cellulase and xylanase production seems to be influenced by species and media variations.

\section{Kinetics of Growth and Time Course for Xylanase and Cellulase Production}

Literature indicates that fluctuations in culture nutrient at late exponential and stationary growth phase induce the synthesis and release of hydrolytic enzymes including carbohydrases and protease in Bacillus species (Gessesse and Mamo, 1999; Heck et al., 2002). This was observed in this study as the highest production of xylanase and cellulase by the Bacillus strain was attained at stationary growth phase. However a sharp decline in xylanase production was recorded thereafter, probably due to proteolysis and enzyme denaturation; while an increase in cellulase activity after an initial decline was observed, which could be attributed to the production of an isoenzyme as have been suggested in literature (Battan et al., 2007; Ritter et al., 2013). Differing from this study however, xylanase production by $B$. subtilis ASH was initiated at $24 \mathrm{~h}$ and attained maximum yield at $72 \mathrm{~h}$ (Sanghi et al., 2008). On the other hand, lowest and maximum xylanase production by Gracilibacillus sp. TSCPVG was attained at logarithmic and stationary growth phase respectively (Giridhar and Chandra, 2010).

\section{Effect of Carbon Source Inducers for Holocellulase Production}

Similar to the carbon source for maximum xylanase production obtained in this investigation, birchwood xylan induced highest xylanase production $\left(3.5 \mathrm{U} \mathrm{mL}^{-1}\right)$ by Gracibacillus sp. TSCPVG (Giridhar and Chandra, 2010). Nagar et al. (2012) reported wheat bran as the best inducer of xylanase production by Bacillus pumilus SV-205. In another study, xylose and arabinose were reported as having the highest inducing influence on xylanase production by Paenibacillus sp. $\mathrm{N}_{1}$, with respective activity of 40.60 and $38.70 \mathrm{IU} \mathrm{mL}^{-1}$ (Pathania et al., 2012); while Adhyaru et al. (2014) reported that xylose, sucrose and starch with respective xylanase activity of $145.13,115.41$ and $110 \mathrm{IU} \mathrm{mL}^{-1}$ were the carbon sources that induced appreciable xylanase production by $B$. altitudinis. On the other hand, cellulase production is generally induced by CMC in most bacterial strains (Heck et al., 2002). Documented reports have shown that the spectrum of enzymes produced by bacterial strains in response to different carbon inducers is specie specific, therefore variations among different bacterial strains can usually be observed (Heck et al., 2002).

\section{Conclusion}

The upsurge of interest in holocellulolytic enzymes production is attributed to the need to meet the increasing demand for these enzymes. Among other strategies, isolation of novel high-yielding bacterial strain and process enhancement could aid in meeting the demand for these enzymes. The characteristics of rapid growth and metabolic turn over potentiate bacterial strains for efficient holocellulases producers. In this study holocellulolytic enzymes production by Bacillus sp. strain SAMRC-UFH9 was improved by several folds; 0.006-0.061 and 0.23-16.6 ( $\left.\mathrm{U} \mathrm{mL}^{-1}\right)$ for cellulase and xylanase respectively. In addition to producing high activity cellulase-free xylanase, very low activity cellulase even in the presence of cellulose substrate was also recorded. Therefore the bacillus strain could be an important source of xylanase in biotechnological 
application, especially in processes requiring low cellulase or cellulase-free xylanase such as the textiles, pulp and paper industries.

\section{Acknowledgment}

We are grateful to the University of Fort Hare and the South Africa Medical Research Council for financial support.

\section{Author's Contributions}

Evelyn N. Fatokun: Performed the bench work, data analysis and prepared the manuscript.

Uchechukwu U. Nwodo: Revised and proof read the manuscript from draft to final version.

Ademola O. Olaniran: Performed the gene sequencing of the bacterial isolate and proof read the final version of the manuscript.

Anthony I. Okoh: Supervised the study and proof read the final version of the manuscript.

\section{Conflicts of Interest}

The authors declare no conflict of interest.

\section{References}

Abo-State, M.A.M., M.F. Ghaly and E.M. Abdellah, 2013. Optimization of cellulase(s) and xylanase production by thermophilic and alkaliphilic Bacillus isolates. Am. Eur. J. Agric. Environ. Sci., 13: 553-564.

Abou-Taleb, K.A.A., W.A. Mashhoor, S.A. Nasr, M.S. Sharaf and H.H.M. Abdel-Azeem, 2009. Nutritional and environmental factors affecting cellulase production by two strains of cellulolytic bacilli. Aust. J. Basic Applied. Sci., 3: 2429-2436.

Acharya, S. and A. Chaudhary, 2012. Optimization of fermentation conditions for cellulases production by Bacillus licheniformis MVS1 and Bacillus sp. MVS3 Isolated from Indian Hot Spring. Braz. Arch. Biol. Technol., 55: 497-503. DOI: $10.1590 / \mathrm{S} 1516-89132012000400003$

Adhyaru, D.N., N.S. Bhatt and H.A. Modi, 2014. Enhanced production of cellulase-free, thermo-alkali-solventstable xylanase from Bacillus altitudinis DHN8, its characterization and application in sorghum straw saccharification. Biocat. Agric. Biotech., 3: 182-190. DOI: $10.1016 /$ j.bcab.2013.10.003

Ali, S.M., S.H. Omar and N.A. Soliman, 2013. Coproduction of cellulase and xylanase enzymes by thermophilic Bacillus subtilis 276NS. Int. J. Biotechnol. Wel. India, 2: 65-74.

Amore, A., O. Pepe, V. Ventorino, A. Aliberti and V. Faraco, 2013. Cellulolytic Bacillus strains from natural habitats - A review. Chimica Oggi. Chem. Today, 31: 49-52.
Anbu, P., S.C.B. Gopinath, A.C. Cihan and B.P. Chaulagain, 2013. Microbial enzymes and their applications in industries and medicine. BioMed. Res. Int., 2013: 1-2.

Bai, S., M. Ravi Kumar, D.J. Mukesh Kumar, P. Balashanmugam and M.D. Bala Kumaran et al., 2012. Cellulase Production by Bacillus subtilis isolated from cow dung. Arch. Applied Sci. Res., 4: 269-279.

Banerjee, G., J.S. Scott-Craig and J.D. Walton, 2010. Improving enzymes for biomass conversion: A basic research perspective. Bioenerg. Res., 3: 82-92. DOI: $10.1007 / \mathrm{s} 12155-009-9067-5$

Bano, S., S.A.U. Qader, A. Aman, M.N. Syed and K. Durrani, 2013. High production of cellulose degrading endo-1,4- $\beta$-D-glucanase using bagasse as a substrate from Bacillus subtilis KIBGE HAS. Carbohyd. Polym., 91: 300-304. PMID: 23044136

Battan, B., J. Sharma, S.S. Dhiman and R.C. Kuhad, 2007. Enhanced production of cellulase-free thermostable xylanase by Bacillus pumilus ASH and its potential application in paper industry. Enz. Microbial. Technol., 41: 733-739. DOI: 10.1016/j.enzmictec.2007.06.006

Bibi, Z., A. Ansari, R.R. Zohra, A. Aman and S.A.U. Qader, 2014. Production of xylan degrading endo-1, 4- $\beta$-xylanase from thermophilic Geobacillus stearothermophilus KIBGE-IB29. J. Rad. Res. Applied Sci., 7: 478-485. DOI: 10.1016/j.jrras.2014.08.001

Cosa, S., L.V. Mabinya, O. Ademola, A.O. Olaniran and A.I. Okoh, 2012. Production and characterization of bioflocculant produced by Halobacillus sp. Mvuyo isolated from bottom sediment of Algoa Bay. Envt. Tech., 33: 967-973. DOI: $10.1080 / 09593330.2011 .603755$

De Souza Vandenberghe, L.P., J.C. de Carvalho, N. Libardi, S. Rodrigues and C.R. Soccol, 2016. Microbial enzyme factories: Current Trends in Production Processes and Commercial Aspects. In: Agro-Industrial Wastes as Feedstock for Enzyme Production: Apply and Exploit the Emerging and Valuable use Options of Waste Biomass, Dhillon, G.S. and S. Kaur (Eds.), Elsevier Science, London, ISBN-10: 012802612X, pp: 1-18.

Deka, D., S.P. Das, N. Sahoo, D. Das and M. Jawed et al., 2013. Enhanced cellulase production from Bacillus subtilis by optimizing physical parameters for bioethanol production. ISRN Biotechnol., 2013: 1-10. PMID: 25937985

Fatokun, E.N., U.U. Nwodo and A.I. Okoh, 2016. Classical optimization of cellulase and xylanase production by a marine Streptomyces species. Applied Sci., 6: 286-286. DOI: 10.3390/app6100286

Gaur, R., S. Tiwari, P. Rai and V. Srivastava, 2015. Isolation, Production and characterization of thermotolerant xylanase from solvent tolerant Bacillus vallismortis RSPP-15. Int. J. Polym. Sci., 2015: 1-10. DOI: $10.1155 / 2015 / 986324$ 
Gautam, S.P., P.S. Bundela, A.K. Pandey, J. Khan and M.K. Awasthi et al., 2011. Optimization for the production of cellulase enzyme from municipal solid waste residue by two novel cellulolytic fungi. Biotechnol. Res. Int., 2011: 1-8. DOI: $10.4061 / 2011 / 810425$

Gessesse, A. and G. Mamo, 1999. High-level xylanase production by an alkaliphilic Bacillus sp. by using solid-state fermentation. Enz. Microb. Technol., 25: 68-72. DOI: 10.1016/S0141-0229(99)00006-X

Giridhar, P.V. and T.S. Chandra, 2010. Production of novel halo-alkali-thermo-stable xylanase by a newly isolated moderately halophilic and alkali-tolerant Gracilibacillus sp. TSCPVG. Process Biochem., 45: 1730-1737. DOI: 10.1016/j.procbio.2010.07.012

Goyal, V., A. Mittal, A.K. Bhuwal, G. Singh and A. Yadav et al., 2014. Parametric optimization of cultural conditions for carboxymethyl cellulase production using pretreated rice straw by Bacillus sp. 313SI under stationary and shaking conditions. Biotechnol. Res. Int., 2014: 1-7. PMID: 24868469

Heck, J.X., P.F. Hertz and M.A.Z. Ayub, 2002. Cellulase and xylanase productions by isolated amazon Bacillus strains using soybean industrial residue based solidstate cultivation. Braz. J. Microbiol., 33: 213-218. DOI: $10.1590 / \mathrm{S} 1517-83822002000300005$

Irfan, M., M. Nadeem, Q. Syed and S. Baig, 2012. Effect of medium composition on xylanase production by Bacillus subtilis using various agricultural wastes. Am. Eur. J. Agric. Environ. Sci., 12: 561-565.

Kazemi, A., S. Rasoul-Amini, M. Shahbazi, A. Safari and Y. Ghasemi, 2014. Isolation, identification and media optimization of high-level cellulase production by Bacillus sp. BCCS A3, in a fermentation system using response surface methodology. Prep. Biochem. Biotechnol., 44: 107-118. PMID: 24152098

Kim, S.J., C.M. Lee, B.R. Han, M.Y. Kim and Y.S. Yeo et al., 2007. Characterization of a gene encoding cellulase from uncultured soil bacteria. FEMS Microbiol. Lett., 282: 44-51. PMID: 18355282

Kumar, L., D. Kumar, S. Nagar, R. Gupta and N. Garg et al., 2014. Modulation of xylanase production from alkaliphilic Bacillus pumilus VLK-1 through process optimization and temperature shift operation. 3 Biotech., 4: 345-356. DOI: $10.1007 / \mathrm{s} 13205-013-0160-2$

Kumar, V. and T. Satyanarayana, 2014. Production of endoxylanase with enhanced thermostability by a novel polyextremophilic Bacillus halodurans TSEV1 and its applicability in waste paper deinking. Proc. Biochem., 49: 386-394. DOI: 10.1016/j.procbio.2013.12.005

Lordan, S., R.P. Ross and C. Stanton, 2011. Marine bioactives as functional food ingredients: Potential to reduce the incidence of chronic diseases. Mar. Drugs, 9: 1056-1100. DOI: 10.3390/md9061056

Maki, M.L., A. Idrees, K.T. Leung and W. Qin, 2012. Newly isolated and characterized bacteria with great application potential for decomposition of lignocellulosic biomass. J. Mol. Microbiol. Biotechnol., 22: 156-166. PMID: 22832891

Miller, G.L., 1959. Use of dinitrosalicylic acid reagent for determination of reducing sugar. Analyt. Chem., 37: 426-428. DOI: 10.1021/ac60147a030

Mincer, T.J., P.R. Jensen, C.A. Kauffman and W. Fenical, 2002. Widespread and persistent populations of a major new marine Actinomycete taxon in ocean sediments. Applied Environ. Microbiol, 68: 5005-5011.

DOI: 10.1128/AEM.68.10.5005-5011.2002

Motta, F.L., C.C.P. Andrade and M.H.A. Santana, 2013. A review of xylanase production by the fermentation of xylan: Classification, characterization and applications. INTECH, 10: 251-271. DOI: 10.5772/53544

Mukesh Kumar, D.J., P.D. Poovai, P.C.L. Kumar, Y.S. Saroja and A. Manimaran et al., 2012. Optimization of Bacillus cereus MRK1 cellulase production and its biostoning activity. Der. Pharmacia. Lett, 4: 881-888.

Nagar, S., A. Mittal, D. Kumar and V.K. Gupta, 2012. Production of alkali tolerant cellulase free xylanase in high levels by Bacillus pumilus SV-205. Int. J. Biol. Macromol., 50: 414-420. PMID: 22227307

Pathania, S., N. Sharma and S.K. Verma, 2012. Optimization of cellulase-free xylanase produced by a potential thermoalkalophilic Paenibacillus sp. $\mathrm{n}_{1}$ isolated from hot springs of northern himalayas in India. J. Microbiol. Biotech. Food Sci., 2: 1-24.

Peterson, R. and H. Nevalainen, 2012. Trichoderma reesei RUT-C30--thirty years of strain improvement. Microbiol., 158: 58-68. PMID: 21998163

Prakash, P., S.K. Jayalakshmi, B. Prakash, M.M. Rubul and K. Sreeramulu, 2012. Production of alkaliphilic, halotolerent, thermostable cellulase free xylanase by Bacillus halodurans PPKS-2 using agro waste: Single step purification and characterization. World J. Microbiol. Biotechnol., 28: 183-192. PMID: 22806794

Ray, A.K., A. Bairagi, K.S. Ghosh and S.K. Sen, 2007. Optimization of fermentation conditions for cellulase production by Bacillus subtilis CY5 and Bacillus circulans TP3 isolated from fish gut. Acta Ichthyologica Et Piscatori, 37: 47-53.

Ritter, C.E.T., M. Camassola, D. Zampieri, M.M. Silveira and A.J.P. Dillon, 2013. Cellulase and xylanase production by Penicillium echinulatum in submerged media containing cellulose amended with sorbitol. Enzym. Res., 2013: 1-9. DOI: 10.1155/2013/240219

Saini, J.K., R. Saini and L. Tewari, 2014. Lignocellulosic agriculture wastes as biomass feedstocks for secondgeneration bioethanol production: Concepts and recent developments. 3 Biotech, 5: 337-353. DOI: $10.1007 / \mathrm{s} 13205-014-0246-5$

Sanghi, A., N. Garg, J. Sharma, K. Kuhar and R.C. Kuhad et al., 2008. Optimization of xylanase production using inexpensive agro-residues by alkalophilic Bacillus subtilis ASH in solid-state 
fermentation. World J. Microbiol. Biotechnol., 24: 633-640. DOI: 10.1007/s11274-007-9521-5

Sanghi, A., N. Garg, K. Kuhar, R.C. Kuhad and V.K. Gupta, 2009. Enhanced production of cellulase-free xylanase by alkalophilic Bacillus subtilis ASH and its application in biobleaching of kraft pulp. Bio. Resources, 4: 1109-1129.

Saratale, G.D., R.G. Saratale and S.E. Oh, 2012. Production and characterization of multiple cellulolytic enzymes by isolated Streptomyces sp. MDS. Biomass Bioenergy, 47: 302-315. DOI: $10.1016 /$ j.biombioe.2012.09.030

Sarka, N. and K. Aikat, 2014. Aspergillus fumigatus NITDGPKA3 provides for increased cellulase production. Int. J. Chem. Eng., 2014: 1-9. DOI: $10.1155 / 2014 / 959845$

Satyanarayana, T. and S. Adhikari, 2006. Application of Alkalistable and Thermostable Microbial Xylanolytic Enzymes in Pulp and Paper Industry. In: Microbes: Health and Environment, Chauhan, A.K. and A.I.K. Varma (Eds.), I. K. International Pvt Ltd, New Delhi, ISBN-10: 8188237515, pp: 356-388.

Sepahy, A.A., S. Ghazi and M.A. Sepahy, 2011. Costeffective production and optimization of alkaline xylanase by indigenous Bacillus mojavensis AG137 fermented on agricultural waste. Enz. Res., 2011: 1-9. DOI: $10.4061 / 2011 / 593624$

Sharma, N., P. Buragohain, D. Tandon and R. Kaushal, 2013. Comparative study of potential cellulolytic and xylanolytic bacteria isolated from compost and their optimization for industrial use. J. Agroaliment. Proc. Technol., 19: 284-297.
Singh, J. and P. Kaur, 2012. Optimization of process parameters for cellulase production from Bacillus sp. JS14 in solid substrate fermentation using response surface methodology. Braz. Arch. Biol. Technol., 55: 505-512. DOI: 10.1590/S1516-89132012000400004

Singh, S., V.S. Moholkar and A. Goyal, 2014. Optimization of carboxymethylcellulase production from Bacillus amyloliquefaciens $\mathrm{SS}_{35}$. 3 Biotech, 4: 411-424. DOI: 10.1007/s13205-013-0169-6

Sreedevi, S., S. Sajith and S. Benjamin, 2013. Cellulase producing bacteria from the wood-yards on kallai river bank. Adv. Microbiol., 3: 326-332. DOI: 10.4236/aim.2013.34046

Tamura, K., G. Stecher, D. Peterson, A. Filipski and S. Kumar, 2013. MEGA6: Molecular Evolutionary Genetics Analysis version 6.0. Mol. Biol. Evol., 30: 2725-2729. PMID: 24132122

Tandon, D. and N. Sharma, 2014. Isolation of potential novel cellulolytic and xylanolytic bacteria and optimization of their cultural conditions for enhanced production of cellulase and xylanase. J. Agroaliment. Proc. Technol., 20: 231-240.

van Dyk, J.S., M. Sakka, K. Sakka and B.I. Pletschke, 2010. Identification of endoglucanases, xylanases, pectinases and mannanases in the multi-enzyme complex of Bacillus licheniformis SVD1. Enz. Microbial. Technol., 47: 112-118.

DOI: 10.1016/j.enzmictec.2010.05.004 